\title{
Augmented Reality: Daily Prayers for Preschooler Student
}

\author{
https://doi.org/10.3991/ijim.v12i1.7269 \\ Hendra Pradibta \\ State Polytechnics of Malang, Indonesia \\ hendra.pardibta@polinema.ac.id
}

\begin{abstract}
Education is one of the aspects that many synthesized with technology. Yet, this is contrary to the fact that where most of the learning materials are still based on text. This research aims to develop an alternative learning media by implementing Augmented Reality Technology for Preschooler students. Augmented Reality (AR) is an application that can combine the virtual object as text, pictures and animation into the real world. Development of Augmented Reality application uses Web Aurasma Based Studio, with learning materials of daily prayer for preschool student. The development of the characters and the animations were using Adobe Illustrator and Adobe After Effects. The results of the study showed that technology Augmented Reality can be used as an alternative learning media especially in the learning process in Preschool Al Furqon. This is because the content Augmented Reality in the form of animation can gives more understanding and attention for preschool student to follow the learning process
\end{abstract}

Keywords-Augmented Reality, Learning Media, Aurasma, Daily Prayer

\section{Introduction}

In early education stage, education is not only focuses to develop brain function but it is also intended to soft motoric ability development. The development of soft motoric ability can be done by training children to do routine activities and tasks such as playing puzzle, blocks, inserting objects into the hole in the appropriate forms [1], shearers, attached and coloring. Soft motoric is the ability to relate to physical skills involving small muscles and coordination of the eyes and the hand. In a research done by Clark and Dunser [2], it is said that the Augmented Reality in the form of a book (learning media) can help the reader to interact with the content that is found in the book; moreover, they can easier understanding the learning materials. Hence, it is also increase their soft motoric abilities, communication skill and other basic skill [3]

In this research, the implementation of Augmented Reality was build by entering materials about daily prayers within audiovisual form. It was expected that by using an interactive and attractive content, preschool student could be easier to understand and memorize the daily prayer. 
The purpose of this research is to introduce the utilization of Augmented Reality for education to the community especially in early education stage. Moreover, it is also as an alternative media in teaching daily prayers for Preschool Student

\section{$2 \quad$ Literature Review}

\subsection{Augmented Reality}

Ronald T Azuma [4] explains that Augmented Reality is a technology that combines the real world and virtual, through an interactive, real time and 3 dimensional animation. The development of this technology is intended to obtain a system that combines the information in the real world with digital information. Augmented Reality technology first developed based on the detection of the image on a picture that is called as a marker. Picture that used in the development of this technology is a blackframed picture with specific patterns.

The use of Augmented Reality more widespread, not only in the field of technology but has implemented in many areas such as health, military, sports, property, manufacturing industry [5] and education.

The implementation of Augmented Reality has been used by some researchers, such as Bai [6] which is used Augmented Reality technology as learning media for Autistic children, Brandao [7] creates an application "An Augmented Reality Gamebook" for children with Autism Spectrum Disorder (ASD), Hafiza [8] Research on the framework of learning using Augmented Reality (Digital Story telling) for remedial student. The next research is the utilization of Augmented Reality textbook for future blended education by Ivanova [9]. Other applied Augmented reality technology was developed by Putu [10], which developed Balinese Dance application using AR technology approach.

\subsection{Augmented Reality Application}

Nowadays there are various kinds of Augmented Reality applications that can be applied in several aspects. Additionally, some applications can be utilize to develop Augmented Reality application, such as: Augment, Aurasma, BilppAR, Junaio, Screen, Wikitude, and Zappar. This research was applied Aurasma as application to develop daily prayers learning media. Aurasma is an Augmented Reality platform that provides ease for the user to create and Augmented Reality publish content [11].

Aurasma is a Web Based application that provides the ability for users to view and create content of Augmented Reality. Aurasma utilize the camera from mobile devices to interact with the content of Augmented Reality which is added to the marker, object or location that has been made as a target image [12]. 


\section{Research Method}

This research can be categorized into the development research, where learning media that developed in this research utilize technology of Augmented Reality. Multimedia Development methods is used in this research, which is developed by LutherSutopo [13]. Multimedia Development was chosen based on the steps of the method, where each stage is explained in detail and specific. There are 6 (six) stages used in Multimedia Development methods, i.e.; concept, design, material collecting, assembly, testing, distribution and implementation

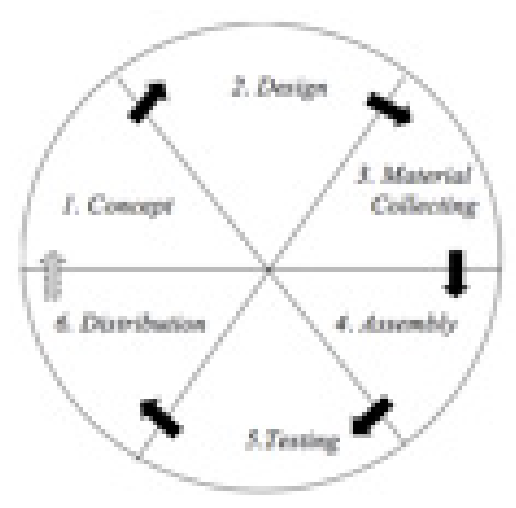

Fig. 1. Multimedia Development Method

\section{$4 \quad$ Research and Discussion}

\subsection{Concept}

Based on the introduction it can be identified that utilization of Augmented Reality technology provides a positive impact to the understanding of learning materials for user[14] [15]. This is the underlying development application based on the Augmented Reality as an alternative learning media.

Table 1. Description of the Application Concept

\begin{tabular}{|l|l|}
\hline \multicolumn{1}{|c|}{ The title } & \multicolumn{1}{c|}{ Daily Prayer AR } \\
\hline Types of Applications & AR-based learning application \\
\hline A user & $\begin{array}{l}\text { The user of the application is identified or intended for Preschool students aged } \\
3-5 \text { years and teachers, therefore the content will be adjusted with the level of } \\
\text { age 3-5 years. }\end{array}$ \\
\hline The Content & The contents are daily prayer for Preschool Student. \\
\hline Pictures & $\begin{array}{l}\text { Use the file format JPG, PNG, AI created using Adobe Illustrator CS5. The } \\
\text { picture is also obtained from the internet. }\end{array}$ \\
\hline Audio and video & Using .MP4 format \\
\hline Animation & The animation on the video is made using Adobe After Effects CS5 \\
\hline
\end{tabular}




\subsection{Design}

Design process was then done by created a marker design and animation layout design, which will be used as the Augmented Reality Content.

Marker. The marker used is the image of the character that is downloaded for free from the Internet and modified according to the needs. The marker is edited using the Adobe Illustrator application, and printed on the media in the form of a Flash Card.

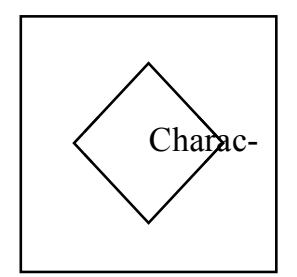

Fig. 2. Marker Design

Animation Layout. The animation layout design contains the image of the characters, the writing of daily prayer in Latin and Arabic language. Each animation will be equipped with sound and audio that encloses the reading in Arabic language, and the meaning of the daily prayer in Indonesian language. Adobe After effects CS5 was used to developed the animation. The results from the development process will be in the form of mp.4.

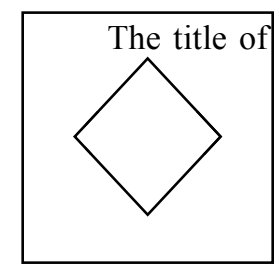

Fig. 3. Animation Layout Design

\subsection{Material Collecting}

The materials needed in the making of this application are obtained from several sources on the Internet with some modifications.

Content . The main content of daily prayers refers to the prayer book of Preschool Al Furqon Merjosari, Malang City, as well as some information interviews with the teachers of Preschool Al Furqon. The materials that became the content of this application are:

- Prayer Before Study

- Prayer before dinner

- Prayer after meal 
- Prayer before sleep

- Prayer after sleep

Pictures. Pictures that are used in this application are obtained from the Internet for free, with modification in certain parts to suit the requirements. Pictures that have been downloaded and then processed using the Adobe Illustrator CS5 application

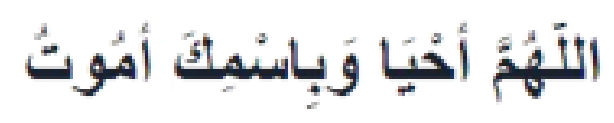

Fig. 4. Prayer before sleep

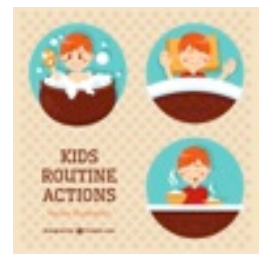

Fig. 5. The Characters

Animation/ Audio Video. Animated Material/audio video is developed using the Adobe After Effects CS5. The process of the animation development was then build by combining some components including pictures, video and audio. The results then saved in .MP4 format. The selection of the format is based on the application specification (Aurasma) as well as the factors the quality of the results of the picture and sound that is adequate.

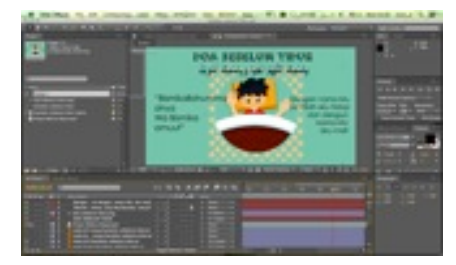

Fig. 6. The application Adobe After Effects

\subsection{Assembly}

The character that is used as a marker is created using adobe illustrator application. The process of making characters adjusted based on the AR content that will be used.

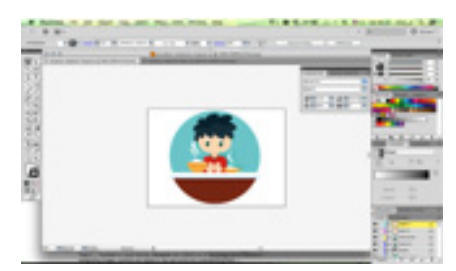

Fig. 7. Making Characters 


\section{Pictures}

Table 2. The picture used as a Marker

\begin{tabular}{|c|l|c|}
\hline No & Name & Format \\
\hline 1 & Prayer Before Study & .png \\
\hline 2 & Prayer Before Meal & Pictures \\
\hline 3 & Prayer After Meal & .png \\
\hline 4 & Prayer Before Sleep & .png \\
\hline 5 & Prayer After Sleep & .png \\
\hline
\end{tabular}

\section{Animations/Audio Video.}
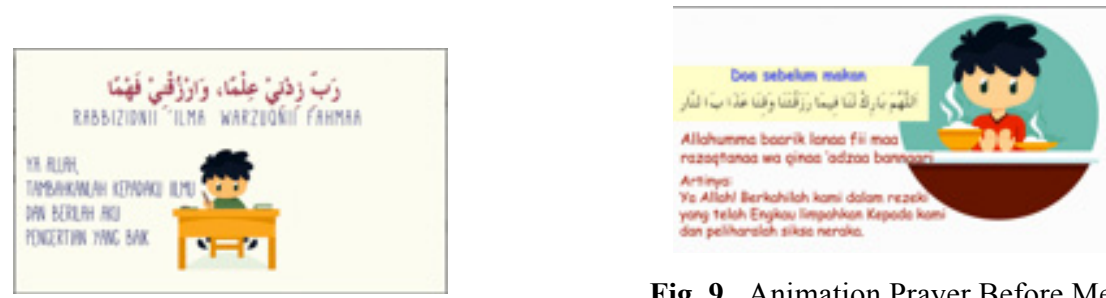

Fig. 9. Animation Prayer Before Meal

Fig. 8. Animation Prayer Before Study

Create Content Aurasma. Aurasma Content creation can be done with the steps as follows:

- Inserting the marker into the Aurasma Web based studio

- Insert the overlay or animation that will be use as Augmented Reality Aurasma content.

- Give the name of AR content available so that later will make it easier to search for content on the application Aurasma AR.

- The last step is sharing Aurasma content, so other users can see it.

\subsection{Testing}

The first test was conducted with the purpose to verify whether the application has been running well in accordance with the design that is made earlier. The tests are performed against the marker that has been made by using mobile devices in this case is using android tablet with 7 inches screen. The test results showed that each of the 
markers could display Augmented Reality content satisfactory. The distance tests showed good results on the range distance 10-30 cm with normal lighting conditions indoor.

Table 3. Distance Test Results

\begin{tabular}{|c|c|l|}
\hline No & Distance & \multicolumn{1}{|c|}{ Status } \\
\hline 1 & $10 \mathrm{~cm}$ & AR Content appear \\
\hline 2 & $20 \mathrm{~cm}$ & AR Content appear \\
\hline 3 & $30 \mathrm{~cm}$ & AR Content appear \\
\hline 4 & $40 \mathrm{~cm}$ & Sometimes appear, sometimes not \\
\hline 5 & $50 \mathrm{~cm}$ & AR can not appear \\
\hline
\end{tabular}

Afterwards, the second phase of the test was performed by showed the Augmented Reality application to the preschool student. Although the students still have to be assisted by the teacher, yet they are looked interested with the application.

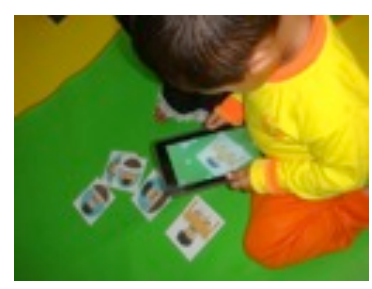

Fig. 10.Implementation

\subsection{Distribution}

The Augmented Reality application material then printed on paper in the form of Flashcard. Flashcard will give ease in the learning process because it is simpler from the book or other learning media.

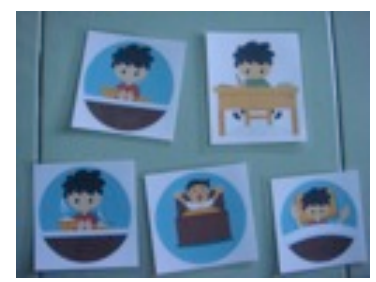

Fig. 11.Flash Card Daily Prayer Children

\section{Conclusion}

From the above research results obtained some conclusions: 
1. Learning Media using Augmented Reality Technology can be used as an alternative media to help the learning process in Preschool Al Furqon.

2. Learning Media using Augmented Reality is able to give more understanding and attention for Preschool students to follow the learning process, especially for daily prayer learning.

\section{References}

[1] ------, "Motorik Kasar vs Motorik Halus." [Online]. Available: www.parenting.co.id/balita/motorik+kasar+vs+motorik+halus. [Accessed: 14-Mar-2016].

[2] A. Clark and A. Dünser, "An interactive augmented reality coloring book," IEEE Symp. $3 D$ User Interfaces 2012, 3DUI 2012 - Proc., no. October, pp. 7-10, 2012. https://doi.org/10.1109/3DUI.2012.6184168

[3] A. Drigas, G. Kokkalia, and A. Economou, "Mobile Learning For Preschool Education," Int. J. Interact. Mob. Technol., vol. 10, no. 4, p. 57, Oct. 2016. https://doi.org/10.3991/ ijim.v10i4.6021

[4] R. Azuma, "A survey of augmented reality," Presence Teleoperators Virtual Environ., vol. 6, no. 4, pp. 355-385, 1997. https://doi.org/10.1162/pres.1997.6.4.355

[5] I. D. Wijaya, "Augmented Reality Brosur Sebagai Media Promosi Calon Mahasiswa Baru Di Politeknik Negeri Malang," J. Tek. Ilmu dan Apl. Negeri Malang, vol. 1, no. 2, p. 107, 2014.

[6] Z. Bai, “Augmenting imagination for children with autism," Proc. 11th Int. Conf. Interact. Des. Child. - IDC'12, p. 327, 2012. https://doi.org/10.1145/2307096.2307159

[7] J. Brandão, P. Cunha, J. Vasconcelos, V. Carvalho, and F. Soares, "An Augmented Reality GameBook for Children with Autism Spectrum Disorders," in The International Conference on E-Learning in the Workplace 2015, 2015, pp. 1-6.

[8] A. Hafiza and B. Z. Halimah, "Digital storytelling design with Augmented Reality technology for remedial students in learning Bahasa Melayu," Glob. Learn Asia Pacific, vol. 2010, no. 1, pp. 3558-3563, 2010.

[9] G. Ivanova, Y. Aliev, and A. Ivanov, "Augmented Reality Textbook for Future Blended Education," Proc. Int. Conf. E-Learning, vol. 14, pp. 130-136, 2014.

[10] N. I. Putu, S. Franza, and K. S. Wibawa, "Application of Basic Balinese Dance Using Augmented Reality on Android,” J. Theor. Appl. Inf. Technol., vol. 90, no. 1, 2016.

[11] S. Phunsa, "Applying Augmented Reality Technology to Promote Traditional Thai Folk Musical Instruments on Postcards," pp. 64-68, 2014.

[12] J.-P. (Joey) van Arnhem, "Mobile Apps for Libraries: 3D Printing Resource Round Up," Charlest. Advis., vol. 17, no. 1, pp. 57-61, 2015. https://doi.org/10.5260/chara.17.1.57

[13] A. . Sutopo, Multimedia Interaktif dengan Flash. Jakarta: Graha Ilmu, 2003.

[14] A. Cascales, D. Pérez-López, and M. Contero, "Study on parents' acceptance of the augmented reality use for preschool education," Procedia Comput. Sci., vol. 25, no. October 2016, pp. 420-427, 2013.

[15] B. Parhizkar, T. A. N. Y. I. Shin, A. H. Lashkari, and Y. A. P. S. Nian, "Augmented Reality Children Storybook ( ARCS )," 2011 Int. Conf. Futur. Inf. Technol., vol. 13, no. January, pp. 1-4, 2011. 


\section{$7 \quad$ Author}

Hendra Pradibta is a teaching staff in the Informatics Management, Department of Information Technology at State Polytechnics of Malang, INDONESIA (email: hendra.pardibta@polinema.ac.id; ndropradibta@gmail.com). 